Article

\title{
Remnant Trees in Enrichment Planted Gaps in Quintana Roo, Mexico: Reasons for Retention and Effects on Seedlings
}

\author{
Angélica Navarro-Martínez ${ }^{1}$, Sebastian Palmas ${ }^{2}$ (D), Edward A. Ellis ${ }^{3, *}$ (D), \\ Pascual Blanco-Reyes ${ }^{4}$, Carolina Vargas-Godínez ${ }^{5}$, Ana Cecilia Iuit-Jiménez ${ }^{5}$, \\ Irving Uriel Hernández-Gómez ${ }^{6}$, Peter Ellis ${ }^{7}$, Alfredo Álvarez-Ugalde ${ }^{1}$, \\ Yavé Guadalupe Carrera-Quirino ${ }^{3}$, Samaria Armenta-Montero ${ }^{3}$ and Francis E. Putz ${ }^{8}$ \\ 1 Agricultura, Sociedad y Ambiente, El Colegio de la Frontera Sur. Av. Centenario Km. 5.5, \\ Pacto Obrero Campesino, 77014 Chetumal, Mexico; manava@ecosur.mx (A.N.-M.); \\ alugal4@gmail.com (A.A.-U.) \\ 2 School of Forest Resources and Conservation, University of Florida, Gainesville, FL 32611, USA; \\ sebaspa@gmail.com \\ 3 Centro de Investigaciones Tropicales, Universidad Veracruzana, 91000 Xalapa, Veracruz, Mexico; \\ yavecarreraq@hotmail.com (Y.G.C.-Q.); samaria.am@gmail.com (S.A.-M.) \\ 4 Domicilio conocido Noh Bec, 77190 Quintana Roo, Mexico; pascualblancoreyes@gmail.com \\ 5 Estudios Sociales y de Sustentabilidad, El Colegio de la Frontera Sur, 77900 Chetumal, Mexico; \\ cavragas@ecosur.edu.mx (C.V.-G.); aciuit@ecosur.edu.mx (A.C.I.-J.) \\ 6 Facultad de Ciencias Agropecuarias, Universidad Veracruzana, 91000 Xalapa, Mexico; urielxal@gmail.com \\ 7 The Nature Conservancy, 4245 North Fairfax Drive, Suite 100 Arlington, VA 22203, USA; pellis@tnc.org \\ 8 Department of Biology, University of Florida, Gainesville, FL 32611, USA; fep@ufl.edu \\ * Correspondence: ellis_eddie@yahoo.com; Tel.: +52-228-839-4149
}

Academic Editor: Timothy A. Martin

Received: 31 May 2017; Accepted: 28 July 2017; Published: 29 July 2017

\begin{abstract}
Natural forest management in the tropics is often impeded by scarcity of advanced regeneration of commercial species. To supplement natural regeneration in a forest managed by a community in the Selva Maya of Mexico, nursery-grown Swietenia macrophylla seedlings were planted in multiple-tree felling gaps, known as bosquetes. Remnant trees are often left standing in gaps for cultural and economic reasons or due to their official protected status. We focus on these purposefully retained trees and their impacts on planted seedlings. Sampled bosquetes were $400-1800 \mathrm{~m}^{2}$, of which remnant trees covered a mean of $29 \%$. Seedling height growth rates over the first 18 months after out-planting more than doubled with increased canopy openness from $0.09 \mathrm{~m}$ year ${ }^{-1}$ under medium cover to $0.22 \mathrm{~m}_{\text {year }}{ }^{-1}$ in full sun. Liana infestations and shoot tip damage were most frequent on seedlings in the open, but, contrary to our expectations, height growth rates were $0.14 \mathrm{~m}_{\text {year }}{ }^{-1}$ faster for liana-infested seedlings than non-infested and did not differ between damaged and undamaged seedlings. Apparently the more rapid height growth of well-illuminated seedlings more than compensated for the effects of lianas or shoot tip damage. Despite the abundance of remnant trees and their negative effects on seedling growth, enrichment planting in bosquetes has potential for community-based natural forest management in the tropics in supplementing natural regeneration of commercial species. One obvious recommendation is to leave fewer remnant trees, especially those of commercial species that are non-merchantable due to stem defects and trees retained for no apparent reason, which together constituted half of the remnant crown cover in the sampled bosquetes. Finally, given the rapid growth of lianas and understory palms in large canopy gaps, at least the most vigorous of the planted seedlings should be tended for at least two years.
\end{abstract}


Keywords: community-based forest management; tropical forestry; gap planting; remnant trees; sustainable forest management

\section{Introduction}

To sustain timber yields in selectively logged tropical forests, silvicultural treatments are often needed [1,2]. The fundamental silvicultural problem is often the scarcity of advanced regeneration (i.e., seedlings, saplings, and poles) of commercial species, especially those that are light-demanding [3]. One way to overcome this limitation is to enrich the natural regeneration by direct seeding or planting nursery-grown seedlings in felling gaps, adjacent to skid trails, or along cleared lines [4-7]. Enrichment planting is also hoped to render forest management financially attractive and thus reduce deforestation for other land uses [8]. For intensification of natural forest management by enrichment planting to succeed, the planted seedlings need to thrive, which depends largely on light conditions that are determined by canopy gap size and shape as well as by the heights of nearby trees $[9,10]$.

After early recognition of the importance of treefall gaps in both temperate [11] and tropical forests [12], research on this topic started to flourish in the 1980s and has continued since, as captured in several literature reviews $[13,14]$. Efforts to clarify what exactly is meant by a gap go back at least to the work of Brokaw [15], who offered the following well-cited definition: "A gap is a 'hole' in the forest extending through all levels down to an average height of $2 \mathrm{~m}$ above ground." The word "average" in this definition reflects an aspect of gap biology that seems to have attracted little attention from researchers-the presence of trees that remain standing within gaps. Many of these remnant trees suffered damage when the gaps were created, and some re-sprouted from broken stems, but they are nevertheless present in many gaps. In this study, we focus on purposefully retained trees in multiple-tree felling gaps that were enriched with seedlings of commercial timber species in the Selva Maya of Mexico.

A statement such as 'seedlings were planted in 400-600 $\mathrm{m}^{2}$ gaps opened by the felling of multiple trees that were then further cleared' conjures images of patch clearcuts, but that is often not the case and certainly does not reflect the conditions in our study site. Treefall gaps, by definition, allow light to penetrate into the forest understory but, as most graphically pointed out in a paper entitled "Forests are not Swiss cheese" [16], even the centers of gaps seldom receive full sun. Not only are gaps shaded by border trees, but many gaps contain remnant trees with crown areas that should perhaps be removed from measurements of gap area.

In response to forestry regulations in Mexico that require and financially support replanting in harvested areas to assure future yields, in some community-owned forests in the Selva Maya on the Yucatan Peninsula of Mexico (i.e., ejidos or communities), nursery-grown seedlings of commercial timber-producing species are planted wherever there is sufficient light to favor their growth such as in $\log$ landings and along skid trails. The species most often planted is Swietenia macrophylla (big-leaf mahogany), a light-demanding taxon that has attracted research attention for nearly a century $[10,17,18]$. While much remains to be learned about this silviculturally problematic but exceedingly valuable species, it is clear that at least in the Selva Maya of Central America and Mexico, its regeneration is favored by large canopy-gaps like those created by hurricanes [19,20]. In managed stands, it is notoriously difficult to mimic the structural results of hurricanes, at least not with low-intensity selective logging [21].

In the Ejido Noh Bec and other community forests of the Selva Maya in Quintana Roo, nursery-grown mahogany seedlings are planted by community members in multiple-tree felling gaps. Before planting, workers clear the gaps of understory vegetation, logging debris, and at least some of the residual trees with the intention of creating openings of $500-2000 \mathrm{~m}^{-2}$ that are locally known as bosquetes. In addition to mahogany, on which we focus in this study, ejidos sometimes enrich 
bosquetes with Lysiloma latisiliqua (tzalam), Caesalpinia mollis (chacteviga), Cedrela odorata (Spanish cedar), Cordia dodecandra (ciricote), and Manilkara zapota (chicozapote).

Mexican ejidos provide good examples of community forest management oriented towards timber production that have managed to conserve more than half of the nation's forest and improve rural livelihoods. While community forestry in Noh Bec has benefited from over 40 years of development and tropical silvicultural research, the majority of ejidos with community forest management are not adopting and implementing improved silvicultural practices that can improve production and sustainability of their community forestry enterprises. Moreover, the lack of tropical silvicultural research in general is also a major constraint in the extension and adoption of improved silvicultural practices in most ejidos of the Mexican tropics [22]. The case of bosquetes in Noh Bec, deserves attention as a potentially viable silvicultural practice that could be used in tropical forestry world-wide.

The objective of this study is to provide information on enrichment planting, as practiced in some community forests in Mexico. We explore the role and impacts on planted mahogany seedlings of the remnant trees that are allowed to remain standing in enrichment planting gaps. We recorded the abundance and species identities of these retained trees, the reasons for their retention, and their impacts on the growth and survival of planted seedlings. In addition to the impacts of shading from remnant trees, we analyze the impacts of shoot tip damage and liana infestations on seedling growth. This focus on decision-making by community members is justified because the ejidos allow workers substantial latitude in interpretation of the bosquete establishment guidelines. Given the on-going and anticipated intensification of natural forest management in the tropics [2], it is important to understand the factors that influence the success of silvicultural interventions such as enrichment planting.

\section{Materials and Methods}

\subsection{Study Area}

Ejido Noh Bec in Quintana Roo, Mexico $\left(19^{\circ} 8^{\prime} \mathrm{N}, 88^{\circ} 20^{\prime} \mathrm{W}\right)$ is surrounded by other forested ejidos and the Sian Ka'an Biosphere Reserve (Figure S1). Of its 24,123 ha, 18,000 ha are dedicated to natural forest management [23]. Mean annual temperature is $26{ }^{\circ} \mathrm{C}$ and mean annual precipitation is $1234 \mathrm{~mm}$ per year of which $70 \%$ falls between the months of May and October [24]. The region suffers hurricanes at nearly decadal intervals [25]. Noh-Bec's vegetation is dominated by closed-canopy semi-deciduous forest that averages $25 \mathrm{~m}$ tall [26] and grows on thin soils over limestone (leptosols, rendzinas and vertisols) $[23,27]$ on level terrain at elevations of 4-35 $\mathrm{m}$ above sea level.

Noh Bec's forests contain about 100 tree species that produce marketable timber, polewood and charcoal, but mahogany is the principal timber species [27]. Noh-Bec manages their forest with a polycyclic system of selective cutting at 25-year intervals with a minimum cutting diameter of $55 \mathrm{~cm} \mathrm{DBH}$ (stem diameter at $1.3 \mathrm{~m}$ ) for mahogany, $35 \mathrm{~cm}$ for other species, and even less for polewood [28]. Other species harvested include Cordia dodecandra (ciricote), Manilkara zapota (chicozapote), Dendropanax arboreus (chacá blanco), and Bursera simaruba (chacá rojo) [29].

\subsection{Bosquete Development}

Enrichment planting in Noh Bec is carried out by "brigades" of workers usually comprised of members of extended families. Other agents involved in the process include the ejido's forest technician and the nursery manager, as well as the Mexican National Forest Comission (CONAFOR), which provides about half the funding through their Cultivo Forestal program.

Potential bosquetes are first selected by the ejido's forest technician based on a harvest map that shows the locations of georeferenced harvest trees; multiple tree felling gaps are preferred for enrichment planting. About a year after the June-July harvests, the selected gaps are prepared for planting by four to five workers armed with chainsaws and machetes. Inside the boundaries of the selected gaps, the understory vegetation is cut and all remnant trees are felled except future crop trees of commercial species, species protected by Mexican forestry regulations [30], trees of value to wildlife, 
and species deemed to be of cultural importance. Small branches and debris are pushed to the sides and large branches and trunks of felled trees are thrown into the adjacent forest or carried out to the roadside for conversion into charcoal in portable kilns. A brigade typically prepares one gap per day for which each worker is paid about US $\$ 8$.

Seedlings for out-planting are grown from seed in a nursery owned and operated by the community. Seedlings are typically 1 year old when out-planted; only healthy seedlings with intact terminal buds are planted. In September-October, planting brigades carry seedlings to planting sites, dig the planting holes, and plant the seedlings in 3 by $3 \mathrm{~m}$ grids; the actual planting is mostly carried out by female workers. Brigades are expected to plant 100 seedlings per person per day, for which each crew member is paid about $\$ 75$ for a 5-day working week. The management plan calls for planted seedlings to be tended (i.e., released from overtopping plants) after two years at which time dead seedlings are replaced, but we saw no evidence of these follow-up activities.

\subsection{Sampling of Enrichment Planted Felling Gaps (i.e., Bosquetes)}

In March 2016, 15 of the 72 bosquetes in the Noh Bec 1000 ha annual cutting area for 2014 were chosen at random using georeferenced data obtained from the local forestry office. One gap was not sampled due to the high density of the stinging treelet, Cnidoscolus acotinifolius. The felling gaps all had level terrain with relatively deep soils with low stoniness, characteristics that favor mahogany growth [10] and typical of Noh Bec. We obtained information on the process of bosquete development from interviews with technicians $(n=3)$ and community brigade members $(n=5)$ involved in Noh Bec's forestry enterprise.

In each of the 14 sampled gaps we measured DBH and identified to species all remnant trees $>5 \mathrm{~cm} \mathrm{DBH}$. We also measured the longest crown diameter and the diameter perpendicular to that axis to calculate projected crown area with the formula for an oval. Stem quality was classified as either good (i.e., potentially acceptable for use as a pole or for saw timber) or bad (i.e., deformed, damaged, or obviously hollow). Finally, the presumed reason for retention of each tree was recorded by a research team member (PBR) who worked as the community's forest technician for 10 years. The set of retention reasons generated by PBR were verified through interviews with five community brigade members involved in bosquete clearing (Table 1).

Table 1. Main characteristics of sampled bosquetes (i.e., enrichment planted gaps) with remnant tree densities as well as their mean and maximum DBH.

\begin{tabular}{|c|c|c|c|c|c|c|}
\hline $\begin{array}{l}\text { Area } \\
\left(\mathrm{m}^{2}\right)\end{array}$ & $\begin{array}{l}\text { Seedlings } \\
(n)\end{array}$ & $\begin{array}{l}\text { Remnant } \\
\text { Trees }(n)\end{array}$ & $\begin{array}{l}\text { Remnants } \\
\text { per Hectare }\end{array}$ & $\begin{array}{l}\text { Canopy Cover } \\
\text { (\% of Gap Area) }\end{array}$ & $\begin{array}{c}\text { Remnant Tree Mean } \\
\text { DBH }(\mathrm{cm})\end{array}$ & $\begin{array}{l}\operatorname{Max} \mathrm{DBH} \\
(\mathrm{cm})\end{array}$ \\
\hline 440 & 117 & 14 & 322 & 43.5 & 18.7 & 35 \\
\hline 560 & 117 & 23 & 413 & 54.3 & 25.1 & 90 \\
\hline 780 & 178 & 16 & 204 & 37.7 & 22.2 & 85 \\
\hline 800 & 220 & 33 & 415 & 27.5 & 15.6 & 37 \\
\hline 920 & 148 & 17 & 184 & 22.6 & 20.2 & 47 \\
\hline 950 & 145 & 17 & 178 & 25.7 & 24.9 & 69 \\
\hline 1030 & 110 & 11 & 107 & 10.1 & 23.4 & 59 \\
\hline 1040 & 324 & 27 & 260 & 30.3 & 17.7 & 64 \\
\hline 1160 & 330 & 31 & 267 & 20.1 & 19.6 & 86 \\
\hline 1170 & 180 & 32 & 275 & 29.2 & 17.9 & 46 \\
\hline 1250 & 162 & 11 & 88 & 13.4 & 22.9 & 47 \\
\hline 1390 & 270 & 25 & 179 & 31.4 & 20.6 & 40 \\
\hline 1710 & 315 & 35 & 204 & 29.0 & 24.8 & 55 \\
\hline 1780 & 266 & 49 & 275 & 30.6 & 19.1 & 54 \\
\hline 1070 * & $206^{*}$ & $24.3 *$ & $241 *$ & $29.0 *$ & $20.9 *$ & $58 *$ \\
\hline
\end{tabular}

Mean for all 14 bosquetes are marked with $\mathrm{a}^{*}$.

We recorded the height and stem diameter $10 \mathrm{~cm}$ above the ground of each nursery-grown mahogany seedling out-planted 18 months prior to measurement. These seedlings could be reliably identified by their position on planting lines. We also recorded the presence or absence of lianas 
on each seedling and whether or not the seedling had suffered one or more incidences of shoot tip damage. We presumed that most of the shoot tip damage was caused by caterpillars of the pyralid moth Hypsipyla grandella, which is common in the area, but did not try to differentiate that effect from browsing damage by deer (Odoicoleus virginianus). We base our analysis on the height growth data because the allometric relationships between height and diameter were nearly the same for seedlings with and without evidence of shoot tip damage (Figure S2). We assume that all seedlings at the time of out-planting were well-formed, had not suffered shoot tip damage, and were very uniform in height. We also assumed that at the time of out-planting, the mahogany seedlings were $54-\mathrm{cm}$ tall, which was the mean height of 256 -month old mahogany seedlings in Noh Bec's nursery $\left(\sigma^{2}=16.1\right)$. Based on a subsample of planting spots in the $3 \times 3 \mathrm{~m}$ planting grids, we estimated seedling survival over the 18 months since planting by noting dead and missing seedlings, which we assumed had died soon after planting.

\subsection{Canopy Cover over Planted Seedlings}

To describe the light environment, we assigned each seedling to one of three crown exposure categories: direct overhead light in a cone of $45^{\circ}$ (open); some diffuse lateral light from below $45^{\circ}$ (medium); and, fully covered (closed). We also recorded whether the shaded seedlings were overtopped by remnant trees, gap border trees, or more rapidly growing adjacent vegetation in the gap. We compared our three-category light-availability metric with gap fraction estimates based on cellphone photographs taken $150 \mathrm{~cm}$ height above each of 46 seedlings and analyzed with GLAMA app (Gap Light Analysis Mobile App, v.3; Masaryk University, Brno, Czech Republic) available through Google Play; photos were taken when the sun was cloud-covered or below the tree line). The clear distinctions between the cover classes give us confidence in our three-point scale (Figure 1).

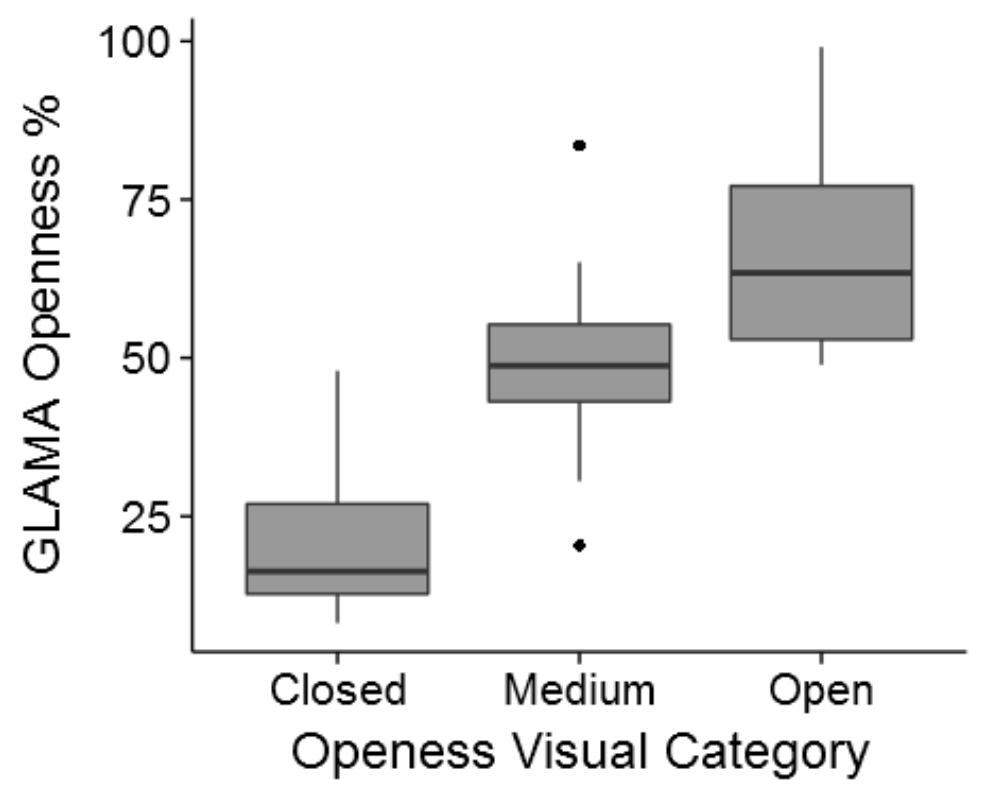

Figure 1. Relationship between canopy openness categories assessed visually and measured with cellphone photos analyzed with GLAMA software (total $n=47$ ). Boxes represent the limits of the first and third quartile and the whiskers extend to the largest or smallest values no further than 1.5 of the inter-quartile range. Points beyond the whiskers are outlying points.

\subsection{Mixed-Effects Modelling}

The seedling data collected are characterized by spatial autocorrelation because they are nested in plots that may differ in characteristics that influence growth (e.g., soil fertility and depth). To correct for potential autocorrelations, we use a mixed-effects model in which unexplained variance is allocated 
into a random effect and the error term. In this case, diameter growth is the dependent variable, plot is considered as a random effect, and canopy openness and liana presence as fixed effects. This mixed-effects analysis was carried out in R 3.3.2 [31] using the lme4 package [32].

\section{Results}

\subsection{Standing Tree Retention in Bosquetes}

The 14 sampled enrichment planted gaps ranged 400-1800 $\mathrm{m}^{2}$ (mean = $1070 \mathrm{~m}$; Table 1$)$. In these gaps, 11-49 trees $>5 \mathrm{~cm} \mathrm{DBH}$ were retained (mean $=24.3$ trees gap ${ }^{-1}$ ), with remnant trees up to $90 \mathrm{~cm}$ DBH. Of all the 341 trees retained of 40 species in the 14 bosquetes, only two were mahogany, both about $30 \mathrm{~cm}$ DBH. On average, $29 \%$ of the gap area in our sampled bosquetes was covered by the crowns of remnant trees $>5 \mathrm{~cm}$ DBH. Their coverage ranged $10-54 \%$ (Table 1 ).

Numerous reasons were provided by workers and other informants for why standing trees were retained in enrichment planted gaps (Table 2). The most commonly retained species, Pouteria reticulata (Sapotacea), is in demand for poles and posts used in the beach resorts to make rustic, palm or grass thatched shelters. Other species that were commonly retained (e.g., Brosimum alicastrum, Sabal japa, and Manilkara zapota) are all recognized for their importance to wildlife but have other uses as well. Of the commonly retained species, Mexican governmental regulations prohibit the felling of three species, one of which is a palm, Cryosophila argentea and the other two are dichotyledonous trees, Vitex gaumeri and Trichilia minutiflora.

Table 2. Reasons provided by workers in enrichment planting brigades for not felling trees of the most commonly retained tree species (including palms where noted) in bosquetes.

\begin{tabular}{|c|c|c|c|c|c|c|}
\hline \multirow{2}{*}{ Species } & \multirow{2}{*}{$n$} & \multicolumn{5}{|c|}{ Reasons for Retention } \\
\hline & & Timber & Cultural & Posts & Regulation & Fauna \\
\hline Pouteria reticulata & 80 & & & $\bullet$ & & \\
\hline Brosimum alicastrum & 35 & & $\bullet$ & & & • \\
\hline Sabal japa (palm) & 29 & & - & & & \\
\hline Manilkara zapota & 28 & - & & & & $\bullet$ \\
\hline Pouteria campechiana & 11 & - & & & & - \\
\hline Bursera simaruba & 10 & $\bullet$ & $\bullet$ & & & \\
\hline Cryosophila argentea (palm) & 10 & & & & $\bullet$ & \\
\hline Diospyros cuneata & 10 & & & $\bullet$ & & $\bullet$ \\
\hline Simira salvadorensis & 10 & $\bullet$ & & & & \\
\hline Trichilia minutiflora & 10 & & & • & $\bullet$ & \\
\hline Guettarda elliptica & 9 & $\bullet$ & & & & \\
\hline Simarouba amara & 9 & $\bullet$ & & & & \\
\hline Gymnanthes lucida & 8 & $\bullet$ & & & & \\
\hline Alseis yucatanensis & 7 & & • & & & \\
\hline Dendropanax arboreus & 7 & $\bullet$ & & & & \\
\hline Metopium brownei & 7 & $\bullet$ & & & & \\
\hline Vitex gaumeri & 7 & & & $\bullet$ & $\bullet$ & \\
\hline Coccoloba cozumelensis & 6 & & & $\bullet$ & & $\bullet$ \\
\hline Sideroxylon gaumeri & 6 & & & $\bullet$ & & \\
\hline Protium copal & 4 & - & • & & & \\
\hline
\end{tabular}

$n$ is the number retained trees found inside sampled bosquetes.

In terms of crown cover by retained trees in bosquetes, undersized individuals of species harvested for polewood and timber were most important (Table 3). Despite being of commercial species, 20.5\% had stem defects that would likely render them non-marketable. Cultural reasons for tree retention were also invoked frequently. Although government regulations that protect certain species were often mentioned as an impediment to management and the fines levied were described as unduly onerous, only $<1 \%$ of the crown cover by remnant trees in bosquetes resulted from abiding by these regulations. 
Table 3. Mean percentage of the area of bosquetes covered by the crowns of trees retained for different reasons.

\begin{tabular}{ccc}
\hline Motivation for Retention & \% Cover in Planted Gaps Mean & Range \\
\hline Timber & $11 \%$ & $3-27 \%$ \\
Cultural & $10 \%$ & $1-22 \%$ \\
Posts & $7 \%$ & $2-11 \%$ \\
Regulation & $1 \%$ & $0-2 \%$ \\
ANY & $29 \%$ & $10-54 \%$ \\
\hline
\end{tabular}

\subsection{Planted Seedling Survival, Growth, Shoot Tip Damage, and Liana Infestations}

A mixed model was fitted to explain height growth as a function of canopy openness, shoot tip damage, and liana infestations, which allocated variance to each bosquete. Mahogany seedling growth rates increased with canopy openness. Seedlings under a moderately open canopy had grown $0.09 \mathrm{~m}$ year ${ }^{-1}$ more per year than those under a closed canopy $(t$-value $=3.3, p<0.05)$ whereas seedlings in the open category grew $0.22 \mathrm{~m}$ year $^{-1}$ faster than those in the closed exposure category $(t$-value $=5.8 ; p<0.05 ;$ Figure 2A). Lianas infested $37 \%$ of the planted seedlings but, contrary to our expectation, height growth rates of liana-infested seedlings were $0.14 \mathrm{~m} \mathrm{year}^{-1}$ faster than those of liana-free seedlings ( $t$-value $=5.5, p<0.01$; Figure $2 \mathrm{~B}$ ). We also found, as is often reported, that shoot tip damage was more frequent in the open ( $38 \%$ of seedlings) and under medium cover $(28 \%)$, than in the shade (18\%); there was only a small difference in the heights of damaged and undamaged seedlings. Damaged trees grew $0.02 \mathrm{~m}_{\text {year }}{ }^{-1}$ faster than undamaged ones ( $t$-value $=0.722$; Figure $2 \mathrm{C}$ ). Apparently the more rapid height growth rates of well-illuminated seedlings more than compensated for the slightly higher incidence of shoot tip damage. Based on dead and missing seedlings along the sampled planting lines we estimate that about $80 \%$ of the out-planted seedlings survived.
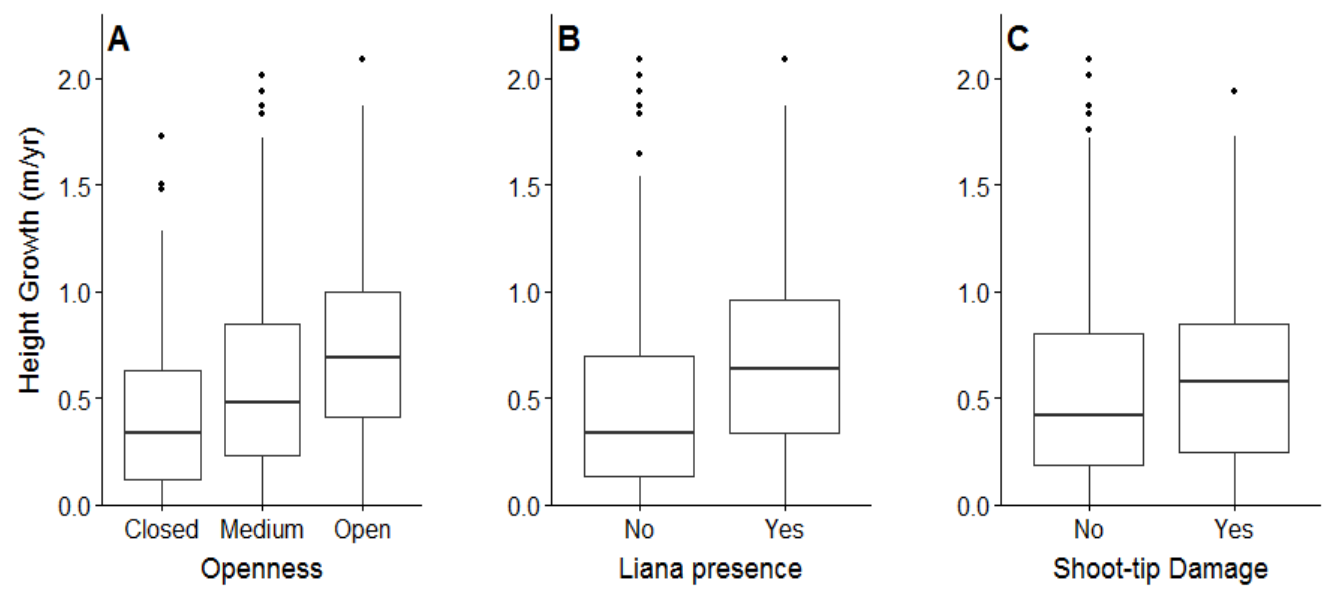

Figure 2. Annual rates of height growth of out-planted mahogany seedlings based on (A) canopy openness category; (B) whether or not they were liana-infested; and (C) whether or not they had suffered shoot tip damage.

\section{Discussion}

\subsection{Tree Retention in Bosquetes}

It is not always clear in the silviculture and forest ecology literature how remnant trees in felling and natural treefall gaps are accounted for by researchers. In some cases, enrichment planted gaps are completely cleared of remnant vegetation, as in the gaps studied by Keefe et al. [33] where liana tangles were completely cleared by bulldozers. Similarly, in the gap planting experiments described by Schwartz et al. [7], all remnant trees were cut prior to planting. 
Perhaps tree retention in gaps to be enriched by planting is an issue of more relevance to community than industrial forestry. At least in community operations in which workers have substantial autonomy in their interpretation of management guidelines, it may be challenging for forest supervisors to require trees to be cut that workers believe should be retained for cultural reasons, potential future use, or because they contribute to the maintenance of wildlife populations. This research is perhaps the first to explore the role of remnant trees in tropical silviculture, and further studies on the social, economic and ecological effects of tree retention are needed.

Tree-statured palms were common in many of the enrichment planting gaps we sampled but their retention was seldom due to governmental restrictions. Of the three palm species we encountered, only Cryosophila argentea is protected by federal regulations. Nevertheless, the spiny climber Desmoncus orthacanthos was the only palm species that workers regularly cut in the bosquetes. Avoidance of the often substantial fines for cutting restricted species is reason enough for protection of $C$. argentea, but this species represented only $26 \%$ of the remnant palms. It appears that the official protection of $C$. argentea is mistakenly extended to other palm species; many workers we interviewed assumed that all palms are protected by law. Perhaps of more relevance is the importance of the other common palm, Sabal japa, in the lives of rural people in the study region. This species is commonly used for roof thatching, and is occasionally harvested for sale to coastal tourist developments [28]. Furthermore, all palms produce large seeds and fleshy fruits that are food for locally valued wildlife. Finally, knowledgeable community forest workers mentioned their belief that tall palms do not compete with planted tree seedlings. This assumption seems to be based on the diffuse shade cast by the small crowns of the common palms in bosquetes. In contrast, there was widespread agreement that the leaves of young palms should be lopped off to provide light to planted seedlings that they can quickly overtop. We did not inventory understory palms, but they were very common in the enrichment planted gaps where they cast shade on many planted seedlings. Palm proliferation is likely to be the result of release by logging of previously suppressed palms plus a pulse of post-harvest regeneration such as observed in neighboring Belize [34].

Trees of commercial species that had not yet reached harvestable size were also not cut in the preparation of enrichment planting gaps, even those with stem defects that would likely cause them to not be marketable. To some extent, the retention of trees with no current or future commercial value for timber or poles might be related to their other uses. For example, M. zapota latex is traditionally harvested for use in natural chewing gum, for which there is still one factory in the region.

\subsection{Planted Seedling Growth in Relation to Shade, Shoot Tip Damage, and Liana Infestations}

The high survival rate of mahogany seedlings planted in the bosquetes $(>80 \%)$ exceeded the expectations of the forest managers [29]. If high survival is the norm, then perhaps in addition to not planting light-demanding seedlings under remnant trees, the overall planting density (currently $3 \times 3 \mathrm{~m}$ ) could be reduced in the future to save time and money.

The small effect of shoot tip damage on the observed height:diameter ratios of planted mahogany seedlings (Figure S2) at least partially justifies the reporting of only height data for seedlings up to 3-4 $\mathrm{m}$ tall [6]. Although seedlings growing in the open were more likely to suffer shoot tip damage than more shaded individuals, which is a pattern reported in the literature $[6,35,36]$, the fastest growing seedlings were also in the open, regardless of the status of their shoot tips. We believe that this counterintuitive finding means that the advantages to mahogany seedlings of high light fully compensates for the shoot tip losses to which they are especially susceptible under those growth-favoring conditions [6,34-36].

That there was no effect of lianas on seedling growth is also counterintuitive and contrasts markedly with their observed deleterious impacts on large trees [37-42]. We believe that this result is related to the recency of the liana infestations and that their ill-effects on seedling growth and stem form will soon become evident. But at least for the first year after planting in cleared gaps, the advantages of high light conditions for mahogany seedling growth are not lost due to concomitant light-favored proliferation of lianas. 
In this study, we relied on the observations of 18-month-old out-planted seedlings grown in the nursery of the ejido Noh Bec. The ejido, with over 40 years of community forestry experience, and model for sustainable tropical forestry worldwide, produces over 15,000 high-quality mahogany plants used for enrichment planting annually. Based on information and observations obtained from the nursery during this study, in addition to previous experience of some authors working in Noh Bec, we are confident in the assumptions that seedlings leave the nursery without shoot tip damage and are on average half a meter tall. Subsequent growth, damage, infestation and shading of the seedlings are also confidently assumed to occur after enrichment planting in bosquetes.

\section{Conclusions}

The observed high survival and growth rates of planted mahogany seedlings in multiple-tree felling gaps, despite the abundance of remnant trees, suggests that enrichment planting has potential for community-based natural forest management in the tropics. Given that communities are now responsible for the management of an estimated $25 \%$ of the world's remaining tropical forests [43], this finding is potentially of substantial importance. Whether this approach to silvicultural intensification will see widespread application will undoubtedly be based on financial viability analyses, but such analyses should reflect the often unique utility functions of communities. In Ejido Noh Bec, for example, the generation of employment for community members is highly valued and therefore needs to be included in calculations of the utility derived from enrichment planting. Whatever the results of these analyses, for mahogany and other light-demanding and high commercial value timber species, this sort of intervention is likely to become more necessary as large, seed-producing trees become more scarce and pressure on the forest to generate income increases.

Based on the observed and well-expected reductions in growth rates of mahogany seedlings planted under remnant trees in multi-tree felling gaps, one obvious recommendation is to leave fewer remnant trees. Exactly which trees should be retained is less clear given the many reasons for their retention, but some reasons are more compelling than others. For example, there would seem to be few objections to cutting small trees of commercial species that have stem defects that will render them non-marketable. Also, forest-managing communities might want to reconsider their lists of species protected for cultural reasons. Finally, for trees that are retained for no obvious reason, which contributed half of the remnant tree crown cover in the bosquetes we studied, forest supervisors should require some justification by the responsible workers.

If workers are instructed to avoid planting under the crowns of remnant trees in planted felling gaps and are paid by the seedling planted, as they are in Ejido Noh Bec, crews will need to work harder to reach their quotas. This financial incentive might motivate them towards more intensive or extensive canopy opening. Finally, given the rapid regrowth of lianas and understory palms, at least the most vigorous of the planted seedlings should be tended for at least two years, as specified in local guidelines and long recommended by tropical foresters [44].

Supplementary Materials: The following are available online at www.mdpi.com/1999-4907/8/8/272/s1, Figure S1: Study area in Ejido Noh Bec in the state of Quintana Roo on the Yucatan Peninsula in Mexico (numbers in main map indicated the 14 sampled bosquetes), Figure S2: Total heights and stem diameters (at $10 \mathrm{~cm}$ above the ground) of planted mahogany seedlings in enrichment planted gaps (bosquetes) that suffered shoot tip damage (blue dots) or that showed no signs of shoot tip replacement (red dots).

Acknowledgments: This study benefited from the hospitality of the people of Ejido Noh Bec. In particular, we thank Gregorio Martínez, Noemi Ferral, Angel Martínez, Alfonso Argüelles Suárez, Gustavo Martínez Ferral, German Eduardo Arreola, Javier Blanco Reyes, Francisco Montalvo Reyes, Jorge Sosa Serrano and José Reyes Ramírez. This research is a part of the Science for Nature and People Partnership (SNAPP) Forest Sharing or Sparing Working Group with funds from an anonymous donor.

Author Contributions: A.N.-M. coordinated the study. S.P. and E.A.E. re-analyzed the data and revised the manuscript. These and all other authors participated fully in field data collection, analysis, and manuscript preparation during a very intensive field course.

Conflicts of Interest: The authors declare no conflict of interest. 


\section{References}

1. Peña-Claros, M.L.; Fredericksen, T.S.; Alarcon, A.; Blate, G.M.; Choque, U.; Leaño, C.; Mostacedo, B.; Pariona, W.; Villegas, Z.; Putz, F.E. Beyond reduced-impact logging: Silvicultural treatments to increase growth rates of tropical trees. For. Ecol. Manag. 2008, 256, 1458-1467. [CrossRef]

2. Putz, F.E.; Romero, C. Futures of Tropical Production Forests; Occasional Paper 143; CIFOR: Bogor, Indonesia, 2015.

3. Mostacedo, B.; Fredericksen, T.S. Regeneration status of important tropical forest tree species in Bolivia: Assessment and recommendations. For. Ecol. Manag. 1999, 124, 263-273. [CrossRef]

4. Peña-Claros, M.L.; Boot, R.G.A.; Dorado-Lora, J.; Zonta, A. Enrichment planting of Bertholethia excelsa in secondary forest in the Bolivian Amazon: Effect of cutting line width on survival, growth and crown traits. For. Ecol. Manag. 2002, 161, 159-168. [CrossRef]

5. Schulze, M. Technical and financial analysis of enrichment planting in logging gaps as a potential component of forest management in the eastern Amazon. For. Ecol. Manag. 2008, 255, 866-879. [CrossRef]

6. Navarro-Cerrillo, R.M.; Griffith, D.M.; Ramirez-Soria, M.J.; Pariona, W.; Golicher, D.; Palacios, G. Enrichment of big-leaf mahogany (Swietenia macrophylla King) in logging gaps in Bolivia: The effects of planting method and silvicultural treatments on long-term seedling survival and growth. For. Ecol. Manag. 2011, 232, 2271-2280. [CrossRef]

7. Schwartz, G.; Lopes, J.C.A.; Mohren, G.M.J.; Peña-Claros, M. Post-harvesting silvicultural treatments in logging gaps: A comparison between enrichment planting and tending of natural regeneration. For. Ecol. Manag. 2013, 293, 57-64. [CrossRef]

8. Keefe, K.; Alavalapati, J.A.A.; Pinheiro, C. Is enrichment planting worth its costs? A financial cost-benefit analysis. For. Policy Econ. 2012, 23, 10-16. [CrossRef]

9. Lopes, J.C.A.; Jennings, S.B.; Matni, N.M. Planting mahogany in canopy gaps created by commercial harvesting. For. Ecol. Manag. 2008, 255, 300-307. [CrossRef]

10. Negreros-Castillo, P.; Mize, C.M. Mahogany growth and mortality and the relation of growth to site characteristics in a natural forest in Quintana Roo, Mexico. For. Sci. 2014, 60, 907-913. [CrossRef]

11. Watt, A.S. On the ecology of British beechwoods with special reference to their regeneration. Part II: The development and structure of beech communities on the Sussex Downs. J. Ecol. 1925, 13, 27-73. [CrossRef]

12. Aubreville, A. Forêt Coloniale. Les Forêts de l'Afrique Occidentale Française; Annals Academie des Sciences Coloniales: Paris, France, 1938; p. 244.

13. Denslow, J.S. Tropical rain-forest gaps and tree species-diversity. Annu. Rev. Ecol. Syst. 1987, 18, 431-451. [CrossRef]

14. Schliemann, S.A.; Bochheim, J.G. Methods for studying treefall gaps: A review. For. Ecol. Manag. 2011, 261, 1143-1151. [CrossRef]

15. Brokaw, N. The definition of treefall gap and its effect on measures of forest dynamics. Biotropica 1982, 14, 158-160. [CrossRef]

16. Lieberman, M.; Lieberman, D.; Peralta, R. Forests are not just Swiss cheese: Canopy stereogeometry of non-gaps in tropical forests. Ecology 1989, 70, 550-552. [CrossRef]

17. Stevenson, N.S. Silvicultural treatment of mahogany forests in British Honduras. Emp. For. J. 1927, 6, $219-227$.

18. Lamb, F.B. Mahogany of Tropical America; University of Michigan Press: Ann Arbor, MI, USA, 1966.

19. Snook, L.K. Stand Dynamics of Mahogany (Swietenia macrophylla King) and Associated Species after Fire and Hurricane in the Tropical Forests of the Yucatan Peninsula, Mexico. Ph.D. Thesis, Yale University, New Haven, CT, USA, 1993.

20. Negreros-Castillo, P.; Mize, C.M. Regeneration of mahogany and Spanish cedar in gaps created by railroad tie extraction in Quintana Roo, Mexico. For. Ecol. Manag. 2008, 255, 308-312. [CrossRef]

21. Snook, L.K. Catastrophic disturbance, logging and the ecology of mahogany (Swietenia macrophylla King): Grounds for listing a major tropical timber species in CITES. Bot. J. Linn. Soc. 1996, 122, 35-46. [CrossRef]

22. Ellis, E.A.; Kainer, K.; Sierra Huelsz, A.; Negreros-Castillo, P.; Rodriguez-Ward, D.; DiGiano, M. Endurance and adaptation of community forest management in Quintana Roo, México. Forests 2015, 6, 4295-4327. [CrossRef]

23. Registro Agrario Nacional (RAN). Plano Definitivo de Tierras de uso Común del Ejido Noh Bec Esc 1:50,000; Ejido Noh Bec: Noh Bec, Quintana Roo, Mexico, 2011. 
24. García, E. Modificaciones al Sistema de Clasificación Climática de Köppen, 4th ed.; UNAM: Mexico City, Mexico, 1987; p. 217.

25. Miranda, F. Vegetación de la Península Yucateca; Colegio de Postgraduados: Chapingo, Mexico, 1978; p. 271.

26. Sánchez-Sánchez, O.; Islebe, G.A. Tropical forest communities in southeastern Mexico. Plant Ecol. 2002, 158, 183-200. [CrossRef]

27. Vester, H.F.M.; Navarro-Martínez, M.A.; López, C.Y.; Canul, U.V.E.; Wetering, M.; Schonck, S. Informe del Proyecto uso y Monitoreo de los Recursos Naturales en el Corredor Biológico Mesoamericano (Áreas Focales Xpujil-Zoh Laguna y Carrillo Puerto); ECOSUR-CONABIO: Chetumal, Mexico, 2005; p. 64.

28. Sierra-Huelsz, J.A.; Kainer, K.A.; Keys, E.; Colli-Balam, S.S. Three stories under the same hut: Market preferences and forest governance drive the evolution of tourism construction materials. For. Policy Econ. 2017, 78, 151-161. [CrossRef]

29. Argüelles, L.A.; Synnott, T.; Gutiérrez, S.; del Ángel, B. Regeneración y silvícultura de la caoba en la Selva Maya Mexicana, ejido Noh Bec. Recur. Nat. Ambient. 2005, 44, 45-52.

30. Secretaria de Medio Ambiente y Recursos Naturales (SEMARNAT). Norma Oficial Mexicana NOM-059-SEMARNAT-2010; Diario Oficial de la Federación (DOF): Mexico D.F., Mexico, 2010.

31. R Core Team. R: A Language and Environment for Statistical Computing; R Foundation for Statistical Computing: Vienna, Austria, 2016.

32. Bates, D.; Machler, M.; Bolker, B.M.; Walker, S.C. Fitting Linear Mixed-Effects Models using lme4. J. Stat. Softw. 2015, 67, 1-48. [CrossRef]

33. Keefe, K.; Schulze, M.D.; Pinheiro, C.; Zweede, J.C.; Zarin, D. Enrichment planting as a silvicultural in the eastern Amazon: A case study of Fazenda Cauaxi. For. Ecol. Manag. 2009, 258, 1950-1959. [CrossRef]

34. Arevalo, B.; Valladarez, J.; Muschamp, S.; Kay, E.; Finkral, A.; Roopsind, A.; Putz, F.E. Effects of reduced-impact selective logging on palm regeneration in Belize. For. Ecol. Manag. 2016, 369, 155-160. [CrossRef]

35. Dickinson, M.B.; Whigham, D.F. Regeneration of mahogany (Swietenia macrophylla) in the Yucatan. Int. For. Rev. 1999, 1, 35-39.

36. Snook, L.K.; Negreros-Castillo, P. Regenerating mahogany (Swietenia macrophylla King) on clearings in Mexico's Maya forest: The effects of clearing method and cleaning on seedling survival and growth. For. Ecol. Manag. 2004, 189, 143-160. [CrossRef]

37. Clark, D.; Clark, D. Distribution and effects on tree growth of lianas and woody hemiepiphytes in a Costa Rican tropical wet forest. J. Trop. Ecol. 1990, 6, 321-331. [CrossRef]

38. Gerwing, J. Testing liana cutting and controlled burning as silvicultural treatments for a logged forest in the eastern Amazon. J. Appl. Ecol. 2001, 38, 1264-1276. [CrossRef]

39. Grauel, W.; Putz, F. Effects of lianas on growth and regeneration of Prioria copaifera in Darien, Panama. For. Ecol. Manag. 2004, 190, 99-108. [CrossRef]

40. Grogan, J.E. Bigleaf Mahogany (Swietenia macrophylla King) in Southeast Para, Brazil: A Life History Study with Management Guidelines for Sustained Production from Natural Forest. Ph.D. Thesis, Yale University, New Haven, CT, USA, 2001.

41. Lowe, R.; Walker, P. Classification of canopy, stem, crown status, and climber infestation in natural tropical forest in Nigeria. J. Appl. Ecol. 1977, 14, 897-903. [CrossRef]

42. Kainer, K.A.; Wadt, L.H.O.; Gomes-Silva, D.A.P.; Capanu, M. Liana loads and their association with Bertholletia excelsa fruit and nut production, diameter growth and crown attributes. J. Trop. Ecol. 2006, 22, 147-154. [CrossRef]

43. Dawkins, H.C. The Management of Natural Tropical High-Forest with Special Reference to Uganda; Commonwealth Forestry Institute Paper 34; Oxford University: Oxford, UK, 1958; p. 155.

44. Petrokofsky, G.; Sist, P.; Blanc, L.; Doucet, J.L.; Finegan, B.; Gourlet-Fleury, S.; Healey, J.R.; Livoreil, B.; Nasi, R.; Peña-Claros, M.; et al. Comparative effectiveness of silvicultural interventions for increasing timber production and sustaining conservation values in natural tropical production forests. A systematic review protocol. Environ. Evid. 2015, 4, 1-7. [CrossRef]

(C) 2017 by the authors. Licensee MDPI, Basel, Switzerland. This article is an open access article distributed under the terms and conditions of the Creative Commons Attribution (CC BY) license (http:/ / creativecommons.org/licenses/by/4.0/). 